\title{
POTRET KEHIDUPAN KOMUNITAS PUNK (STUDI KASUS ANAK PUNK DI LAPANGAN SAMBER KOTA METRO)
}

\author{
Hamdi Abdul Karim \\ Institut Agama Islam Negeri (IAIN) Metro \\ hamdi.abdul.karim@metrouniv.ac.id
}

\begin{abstract}
The research objective: The portrait of the life of the punk community (a case study of punk children in the samber field of Metro City) is to describe the family, socio-cultural and religious life of the punk community in the samber field of Metro city. This research is a qualitative study using a descriptive approach as the main frame of mind. In this study, observation, interviews and documentation as data collection methods. The informants of this research were punk kids who were in the samber field in Metro city. The results of the research, researchers found that there were characteristics of punk children from the community in the samber field when viewed from the way they appeared. Nan not all punk kids in the samber field understand the symbols of the clothes and appearance symbols they use. The punk kid who was in the samber field in Metro City was also from outside the Metro. The motivation for children to enter the punk community is to seek a free life without being regulated by inherent norms and restrain individuals. In addition, there are also those who join the punk community because of the condition of a broken home family, The role of the family is very important in shaping a child's personality. Then the socio-cultural conditions and the condition of a superficial understanding of religion in a person can also influence it.
\end{abstract}

Keywords: Portrait; Life; Punk Community. 


\section{A. PENDAHULUAN}

Komunitas punk merupakan perkumpulan anak muda yang kehidupannya bertujuan mengutamakan untuk kehidupan yang bebas dan tidak penuh dengan tekanan-tekanan yang mengikat namun tetap bertanggung jawab atas kelanjutan hidup mereka sendiri, hal ini dikarenakan mereka ingin hidup bebas dan tanpa pikiran berat yang dapat membebani mereka. Punk ini merupakan salah satu diantara sub sosial kelompok-kelompok sosial yang memiliki ciri khusus dalam memandang hidupnya. ${ }^{1}$ Punk dalam sejarahnya merupakan bagian dari subbudaya yang muncul atau lahir di London (Inggris). Punk merupakan gerakan yang dimotori dan diawali dari anak muda kelas-kelas pekerja yang mengalami masalah ekonomi dan keuangan. Pada masa tahun 1970-an negara Inggris mengalami masalah krisis ekonomi yang menyebabkan munculnya kapitalisme, sehingga pemerintah Inggris menekan, menindas, dan mengeksploitasi kelas pekerja demi pemulihan ekonomi. Kelahiran Punk pada tahun 1970-an dilatar belakangi ketidak puasan akan sistem dan aturan-aturan yang ada di Inggris pada masa itu, sebagai suatu bentuk perlawanan dan ide anak muda dari kelas atau strata pekerja terhadap pemerintahan inggris yang memberlakukan dan menerapkan sistem kapitalisme dengan melakukan berbagai tindakan-tindakan diskriminasi dan eksploitasi kepada para pekerja industri. ${ }^{2}$ Awal kemunculannya sering sekelompok punk berselisih paham dengan kelompok skinhead. Namun pada tahun 1980-an komunitas punk mulai masuk dan merajalela di Amerika, sehingga golongan punk dan skinhead yang sering bermusuhan seakan-akan bersatu, hal ini disebabkan karena mereka mempunyai visi dan semangat yang sama. Sewaktu gerakan perlawanan anak-anak muda dari kelas atau strata pekerja ini masuk ke Amerika, ketika itu Amerika sedang dilanda krisis keuangan dan ekonomi yang ditandai dengan kemerosotan dan kebejatan etika dan moral tokoh-tokoh elit politik negara Amerika, yang menyebabkan tingginya tingkat angka kriminalitas dan pengangguran. Inilah jadi

${ }^{1}$ Ridwan Hardiansyah, Sedikit Cerita Punk dari Bandar Lampung (Yogyakarta: Indie Book Corner, 2011),h. 76.

2 Murti, "Keberagamaan Komunitas Punk" (Fakultas Ushuludin dan Filsafat Universitas Islam Negeri Jakarta, 2007).h 65 
menyebabkan munculnya perlawanan dari Punk dengan menggunakan budaya yang diidentikan dengan bahasa, fashion dan musik. Simbolis perlawanan ini dilakukan oleh individual, maupun kolektif. Budaya perlawanan komunitas punk ini menempatkan dan menjadikan tekanan-tekanan pada aspek politik yang sangat besar dan dalam.

Punk juga merupakan jenis dari aliran genre atau musik yang lahir pada awal 1970an yang merupakan ideologi kehidupan yang cakupannya pada aspek-aspek sosial dan politis. Punk melakukan usaha menyindir penguasa dengan cara-cara mereka sendiri, misalnya melalui musik serta lirik lagu-lagu yang sangat sederhana namun adakalanya menghentak-hentak dan kasar. Punk sebagai suatu pergerakan perlawanan dengan menentang kemapanan dengan cara memainkan bentuk musik menggunakan nada-nada keras dan cara dandanan dalam berpakaian yang sangat menentang keadaan pada umumnya. ${ }^{3}$

Pada tahun 1970-an musik punk berkembang semakin pesat, maka punk mulai menyebar dan berkembang dari Eropa sampai Amerika, Asia, bahkan hingga ke seluruh dunia. Inti dan maksud dari slogan komunitas punk ini adalah semangat penyesuaian diri, bebas berbicara, bebas berpendapat, bebas menyuarakan pendapat dan bebas berekspresi. Punk selalu berbicara tentang kebebasan, kontrol diri tanpa norma yang mengatur dan menjerat, sebagian bahkan banyak diantara masyarakat menganggap anak punk itu tidak lain sama dengan preman, sampah bagi masyarakat, tukang mabuk, dan lain sebagainya. Mereka tidak mengetahui kalau punk punya komunitas tersendiri yang anti di kekang, anti penindasan dan anti kemapanan, namun faktanya di lapangan juga banyak yang mengaku punk tanpa tau makna dan arti punk itu sebenarnya. Punk itu bukan hanya fashion dan musik semata, tapi punk adalah sebuah gaya hidup yang mempunyai idealisme sendiri. Perjalanan dan keberadaan punk itu memiliki tujuan tertentu.

Punk mulai masuk dan berkembang di Indonesia pada akhir tahun 1970 an, akan tetapi baru berkembang pesat pada tahun 1990 an di Jakarta. Hal ini ditandai dengan lahirnya generasi awal Punk di

3 John Martono, A rsita Pinandita, PUNK Fesyen-Subkultur-Identita (Yogyakarta: Halilintar Books, 2009), h.29 
Jakarta dengan nama Young Offeender (Y.O), yang merupakan nama komunitas anak-anak muda yang memiliki arti makna dari simbolsimbol Punk dan Young Offender (Y.O) dengan tampil sebagai kelompok Punk penampilan, bergaya, mohawk, kalung rantai, sepatu boots, spiky hair. Anggota komunitas ini Kebanyakan didominasi oleh kaum lelaki. Komunitas Punk Young Offender (Y.O) ini merupakan suatu kelompok anak-anak muda yang mayoritas anggotanya berasal dari status atau strata kelas menengah dan sebagian dari anak-anak muda yang masih duduk dalam bangku perkuliahan. Young Offender (Y.O) merupakan sebuah sarana atau wadah komunikasi antar sesama komunitas Punk untuk bertemu, bertukar pikiran, bertukar kaos dan kaset antara sesama komunitas Punk dan antar anggota, serta para penggemar musik Punk di Jakarta. ${ }^{4}$

Ada tiga hal yang dikritis, Dalam proses perkembangan sejarah komunitas Punk Jakarta. Pertama, komunitas Punk tidak terlepas dari peranannya sebagai komunitas Punk Jakarta. Gerakan yang diawali oleh anak-anak muda melakukan berbagai perlawanan berupa, kritik, pesan terhadap para penguasa pada saat itu melalui fashion dan gaya hidup. Dengan demikian gerakan perlawanan tersebut perlu dipertanyakan, dikarenakan komunitas Punk di Jakarta ikut masuk dan terlibat ke dalam partai politik yang bernama Partai Rakyat Demokrat (PRD) pada tahun 1997-1999 dengan mengusung sebuah gerakan sama-sama peduli terhadap nasib rakyat serta kondisi sosial, politik saat itu. Kedua, gerakan tersebut pada era tahun 1999. Mulai menemukan puncak kejayaannya, kemajuannya didorong oleh arus reformasi yang membuat semua orang dapat berbicara dengan bebas untuk mengemukakan pendapatnya dimuka umum. Tiga, Komunitas Punk memang terjebak dalam situasi dan kondisi politik praktis sehingga dapat membuat sebagian anggota Punk mundur dari kancah perpolitikan. Dikarenakan banyaknya unsur-unsur politik yang tidak sepaham dengan hati nuraninya anak Punk, serta situasi dan kondisi perpolitikan di Indonesia pada saat itu mengalami stagnasi terhadap aktivitas politik rill. Pada tahapan (fase) ini juga di tahun 2001 komunitas mengalami kemunduran dengan melemahnya

4 Fathun Karib, "Sejarah Komunitas Punk," Artikel ini diakses pada 15 Agustus 2019, dari, Http://jakartabeat.net/musik/kanal-musik/ulasan/147sejarah-komunitaspunk-jakarta-bagian-1.htm. 
sikap politik komunitas punk dan aktivitas politik masyarakat sesudah era reformasi. ${ }^{5}$

Setelah masa itu Komunitas Punk lebih mementingkan penampilan (pose), dan tidak menganggap berpenampilan baik suatu hal penting bagi anak Punk, dengan berpenampilan urak-urakan, compang-camping, berdandan tidak sewajarnya, memakai berbagai atribut Punk seperti kalung, gelang, rantai besar, gembok, rambut dicat, peniti, tindikan, sepatu both, sabuk, dan atribut-atribut lainnya. sebagian masyarakat menilai komunitas Punk ini merupakan komunitas jalanan. Terkadang komunitas Punk tidak terlepas dari perilaku-perilaku menyimpang mulai dari hidup bebas, seks bebas, narkoba, meminum-minuman keras yang mengakibatkan komunitas tersebut terjerumus pada tindakan-tindakan anarkis dan kriminalitas. Keberadaan komunitas Punk yang sepertinya tidak sepenuhnya dapat diterima masyarakat indonesia. Masyarakat indonesia memandang dan menilai mereka dengan pandangan yang negatif. Bagi masyarakat umum komunitas Punk memiliki prilaku menyimpang, diidentikan dengan label negatif yang mengedepankan gaya, fashion dan trend, bukan sebagai anak Punk yang mahir bermain musik dan membuat karya lirik- lirik lagu. Kondisi ini memang disebabkan karena mereka bergaya anak Punk tapi tidak mengetahui makna dan arti Punk sebenarnya dan dipengaruhi juga oleh citra yang dibangun media. ${ }^{6}$ Hal ini membuat kebanyakan anak Punk terjebak dengan kenyataan dan stigma negatif. Karena mereka hanya mengikuti Punk sebagai tempat pelarian atau budaya pamer semata, yang berusaha sembunyi dibalik tirai kebebasan yang sebebasbebasnya tanpa didasari rasa tanggung jawab dan tujuan yang jelas. Kondisi ini sangat bertentangan dan tidak sesuai dengan prinsip dan tujuan yang dipegang oleh komunitas Punk dalam menjalani hidupnya sebagai Punk, yaitu kebebasan didasarkan dengan

${ }^{5}$ Siti Sugiyati, “Fenomena Anak Punk Dalam Perspektif Teori Michel Foucault, Agama Dan Pendidikan" (Fakultas Ilmu Tarbiyah Dan Keguruan Universitas Islam Negeri Syarif Hidayatullah Jakarta, 2014)h4.

${ }^{6}$ Murti, “Keberagamaan Komunitas Punk, (Fakultas Ushuludin dan Filsafat Universitas Islam Negeri Jakarta, 2007)h 8 
tanggung jawab, solidaritas sosial tinggi, persaudaraan, penghargaan terhadap personal dan komunitas.

Komunitas punk ini juga tumbuh dan berkembang di kota Metro. Hal ini penulis temukan dan ketahui seringnya komunitas punk ini melakukan kumpul-kumpul pada malam hari di lapangan samber kota Metro dan juga kegiatan mengamen dijalan jalan protocol dan took-toko yang ada di kota Metro. Seringnya mereka berkumpul pada malam hari dan berpenampilan gaya aneh menimbulkan persepsi atau penilaian masyarakat bahwa mereka menyukai memakai narkoba, minuman keras serta melakukan seks bebas. Kota Metro dikenal dengan slogannya kota pendidikan, artinya Metro ingin mewujudkan masyarakat hidup dengan nilai-nilai pendidikan dan menjadi masyarakat terpelajar dengan ilmu yang telah didapat dibangku pendidikan. Keberadaan komunitas punk di kota metro dengan slogan kota pendidikan sangat perlu untuk dilakukan pengkajian lebih dalam terhadap potret kehidupan komunitas punk ini. Berdasarkan latar belakang di atas maka perlu dilakukan pengkajian tentang potret kehidupan komunitas punk di kota Metro (Studi kasus anak punk di lapangan Samber Kota Metro) dengan melakukan analisis terkait Potret kehidupan keluarga, sosial budaya dan keagamaan komunitas punk ini.

\section{B. METODE PENELITIAN}

Penelitian ini diarahkan untuk memahami dan mendeskripsikan potret kehidupan komunitas punk di kota Metro. Untuk penelitian ini memerlukan pendekatan yang bersifat holistic, pendekatan ini mengasumsikan bahwa keselurahan fenomena perlu dimengerti sebagai suatu sistem yang kompleks dan bahwa yang menyeluruh tersebut lebih besar dan lebih bermakna daripada penjumlahan bagian-bagian. ${ }^{7}$ Penelitian kualitatif ini menggunakan pendekatan deskriptif sebagai kerangka berfikir utama, sesuai dengan tujuan penelitian yaitu untuk memahami dan mendeskripsikan bagaimana proses identitas efikasi diri dan potret kehidupan komunitas punk yang ada di kota Metro. Penelitian kualitatif bersifat alamiah, dalam arti peneliti tidak berusaha untuk

7 Poerwandari, Kristi. E, "Pendekatan Kualitatif Dalam Penelitian Psikologi" (Jakarta, LPSP3 Universitas Indonesia, 2008) h 34. 
memanipulasi setting penelitian, melainkan melakukan studi terhadap suatu fenomena dalam situasi di mana fenomena tersebut ada. ${ }^{8}$ subjek penelitian ialah orang-orang yang bergabung dalam komunitas punk. Dari hasil wawancara eksplorasi terhadap 15 orang. Peneliti melakukan penelusuran terhadap 15 orang sebagai informan awal dan akhirnya memilih 6 orang informan utama. Peneliti mengambil lokasi penelitian di lapangan Samber kota Metro dengan asumsi bahwa peneliti akan mudah untuk mendapatkan responden karena lapangan samber dijadikan tempat berkumpulnya anak punk di malam hari. Teknik penentuan subjrek yang penulis gunakan adalah purposive sampling. Teknik ini adalah pengambilan subjek yang digunakan dengan pertimbangan tertentu dengan berbagai kriteria yang sudah ditentukan. ${ }^{9}$ Adapun kriteria partisipan dalam penelitian ini adalah: a. Remaja yang bergabung dalam komunitas punk; b. Rambut mohawk; c. Memakai piercing; d. Pakaian lusuh; e. Memakai sepatu boots; f. Memakai tatto di tubuhnya. Ketertarikan peneliti pertama kali terhadap remaja yang bergabung dengan komunitas punk yang selanjutnya peneliti kembangkan dan tuangkan ke dalam bentuk penelitian deskriptif kualitatif. Penelitian ini menggunakan metode observasi, wawancara dan dokumentasi sebagai metode pengumpulan data. teknik analisa data yang digunakan melalui open coding, Axial Coding, selective coding

\section{HASIL DAN PEMBAHASAN}

Hasil observasi atau pengamatan terhadap Komunitas punk di kota Metro khususnya yang di lapangan samber penulis menemukan ciri-ciri atau penampilan punk yang terdapat pada komunitas ini, yaitu gaya berpakaian (baju, sepatu. Jaket, pakaian), gaya rambut (spike, mohawk, botak), asesoris (piercing, kalung, gelang, rantai, tato, ikat pinggang, boot). Menurut NA tato yang ada pada tubuhnya akan digambar sesuai dengan perasaannya kepada pemerintah dan juga kondisi atau perasaan dirinya. ${ }^{10}$ Jadi tato merupakan salah satu bentuk cara pelampiasan perasaan atau permasalahan diri dan bentuk kritik kepada pemerintah. Begitu juga penggunaan sepatu

\footnotetext{
8 Ibid,h36.

9 Sugiyono, Metode Penelitian Kuantitatif, Kualitatif dan RED, (Bandung: Alfabeta, 2009).

10 Wawancara dengan NA pada 4 April 2020
} 
boot menurut NA adalah bentuk atau simbol terhadap oknum militer yang melakukan atau menyalahgunakan wewenang. Anak punk lapangan samber ini juga ada yang menindik bagian-bagian pada wajah diantaranya ada yang ditelinga, hidung, pipi, bibir dan lidah. Ketika ditanya terkait ini menurut PMR merupakan ekspresi yang dilakukan sebagai bentuk perlawanan terhadap tata nilai sosial yang ada. ${ }^{11}$ Menindik badan ini merupakan salah satu bentuk usaha membebaskan diri dari norma yang membelenggu. Demikian juga penggunaan rantai pada dompet menurut PMR ini merupakan simbol perlawanan atau sindiran terhadap kaum kapitalisme yang suka mengambil dan mencuri hak-hak orang lain.

Penampilan anak punk dilapangan samber ini menulis juga menemukan penggunaan celana jeans yang ketat dan banyak terdapat sobekan dan tambalan. Ini menurut WL merupakan symbol perlawanan mereka terhadap fesyen atau penampilan yang rapih dan mewah atau glamour. ${ }^{12}$ AJ juga menyatakan bahwa dalam penampilan ia menggunakan kalung dari rantai. penggunaan kalung dari rantainya melambangkan persaudaraan dan simbol solidaritas antar sesama komunitas punk. Rantai ini satu dengan yang lainnya saling mengait ini menggambarkan mereka menganut nilai-nilai kesetaraan. ${ }^{13}$ Dari sini dapat diketahui bahwa penggunaan simbolsimbol yang melekat pada anak punk memiliki makna tertentu. Terhadap pemahaman makna-makna dari penampilan ini penulis juga melakukan wawancara kepada anak punk pada waktu yang berbeda dengan subjek yang lain. Ketika penulis melakukan wawancara dengan SA dan BS yang sedang mengamen diseputaran pasar cendrawasih terkait penggunaan kaos hitam dan jaket berwana hitam yang banyak ditempel aksesoris yang bersangkutan tidak dapat menjelaskan makna dari hal tersebut. Yang bersangkutan lebih menjelaskan sebagai identitas dari komunitasnya tanpa mengetahui makna yang terdapat pada hal tersebut. Begitu juga Ketika penulis menemukan CE yang berprofesi sebagai tukang parkir dilapangan samber, Ketika itu CE menggunakan sepatu Doc Mart yang mana sepatu ini melambangkan bahwa mereka adalah pekerja keras dan

11Wawancara dengan PMR pada 4 April 2020

12 Wawancara dengan WL pada 4 April 2020

13 Wawancara dengan AJ pada 4 April 2020 
mandiri, Ketika peneliti menyampaikan ini kepada $\mathrm{CE}$, ia menyatakan tidak memahami ini idenditas ini. CE hanya mengikuti tren atau gaya penampilan teman-temannya. Berdasarkan uraian terkait penampilan komunitas punk ini dapat diketahui bahwa diantara anak punk yang ada di lapangan samber kota Metro tidak semuanya paham dengan fungsi dan kegunaan pada fesyen yang mereka pakai.

Kondisi yang adanya anak punk tidak paham dengan makna fesye yang mereka gunakan maka penulis menggali informasi terkait pemahaman mereka terhadap sejarah dan jenis-jenis komunitas punk. CE menyatakan ia tidak memahami tentang sejarah dan jenisjenis komunitas punk. Ia ikut punk sebagai salah satu bentuk untuk mencari ketenangan bagi dirinya yang selama ini ia merasa minder dengan lingkungan yang menilai seseorang dari penampilan yang necis sementara ia berasal dari keluarga yang kurang mampu. ${ }^{14} \mathrm{Hal}$ senada juga disampaikan oleh BS bahwa ia secara pribadi tidak terlalu memahami sejarah punk. BS hanya memahami komunitas punk lahir dari salah satu bentuk perlawanan kaum buruh (pekerja) terhadap kaum borjuis ( kapitalis), jenis punk ia tidak terlalu memahami, BS hanya memahami punk itu ada yang berasal dari eropa dan barat. ${ }^{15}$ Ketika ditanya ia mengikut punk yang mana ia sendiri tidak dapat menjelaskan. BS menyatakan ia ikut punk karena ingin hidup bebas dan memiliki teman yang tidak membeda bedakan status sosial. Berdasarkan pernyataan di atas dapat dipahami bahwa tidak semua anak punk yang paham tentang sejarah kemunculan punk, begitu juga terkait jenis-jenis punk yang ada, komunitas punk di lapangan samber kota Metro ini tidak terlalu memahami jenis-jenis punk Ketika diwawancara.

Setiap komunitas punk yang berkembang memiliki ideologi tertentu, Ketika peneliti melakukan wawancara dengan salah seorang anak punk, ia menyatakan bahwa anak punk yang ada di lapangan samber kota metro tidak mengusung salah satu ideologi punk. ${ }^{16} \mathrm{Hal}$ senada juga di sampaikan oleh NA bahwa komunitas yang ada disini tidak mengusung ideologi punk tertentu, yang kami rasakan

\footnotetext{
14 Wawancara dengan CE, pada 10 April 2020

15 Wawancara dengan BS pada 10 April 2020

16 Wawancara dengan WL pada 10 April 2020
} 
berkumpul dan bersatu disini adanya perasaan satu rasa, karsa dan karya yang dapat memberikan ketenangan kepada kehidupan kami sehari-hari. ${ }^{17}$ Berdasarkan hasil wawancara tersebut dapat kita jelaskan bahwa komunitas punk atau anak punk yang ada di lapangan samber kota Metro tidak menganut ideologi tertentu.

Berdasarkan pengamatan penulis komunitas punk yang ada di lapangan samber kota Metro ini memiliki jumlah yang tidak tetap. Menurut CE jumlah anak punk disini tidak tetap, kadang-kadang ada 10 orang 20 orang dan bahkan sampai 45 orang. Kondisi ini menurut CE karena anak punk yang disini tidak hanya berasal dari Metro tapi ada juga yang berasal dari luar Metro seperti Lampung Timur, Lampung Tengah, Bandar lampung dan daerah yang lain. Komunitas punk ini biasanya berkumpul pada malam hari. ${ }^{18}$ Ketika ditanya terkait ketua atau pimpinan punk di lapangan samber kota Metro CE menjelaskan bahwa komunitas punk disini tidak memiliki ketua karena dalam punk itu status sosial seseorang sama tidak ada yang ditinggikan. Hal senada juga diutarakan oleh WL bahwa komunitas punk disini tidak memiliki struktur organisasi, namun kami disini memiliki orang yang kami tuakan yaitu saudara CE.

Aktifitas atau profesi komunitas punk ini dalam kesehariannya beragam. Ada yang berprofesi sebagai tukang parkir, pengamen, buruh dan sebagainya. mereka melakoni berbagai profesi yang penting tidak berada dibawah perintah atau naungan dari instasiinstasi yang menurut komunitas punk bekerja atas kontrol kaum kapitalis. Penghasilan dari profesi yang mereka lakoni selain digunakan untuk keperluan pribadi juga mereka gunakan untuk kebersamaan dalam komunitasnya.

Keberadaan komunitas punk di lapangan samber kota Metro ini yang sering kumpul di malam hari menimbulkan persepsi negatif di masyarakat. Masyarakat menganggap mereka melakukan kegiatan buruk seperti minum-minuman keras. Pandangan ini juga dibenarkan oleh ketua Pol PP kota Metro bahwa pada 16 Februari 2020 komunitas punk di lapangan samber kota Metro ini sempat diamankan oleh pihak kepolisian terkait pesta miras. ${ }^{19}$ Pengamanan

\footnotetext{
17 Wawancara dengan NA pada 10 April 2020

18 Wawancara dengan CE pada 10 April 2020

${ }^{19}$ Wawancara dengan Bapak Imron Kepala Pol PP Kota Metro, pada 13 April
} 2020 
ini dilakukan oleh pihak kepolisian berdasarkan laporan masyarakat. Berdasarkan kejadian ini dapat kita ketahui bahwa komunitas punk yang ada di lapangan samber kota Metro ini terdapat anak-anak punk yang mengkonsumsi minuman keras. Namun hal itu tidak dapat kita generalisasi untuk semua anak punk yang ada di lapangan samber kota Metro.

Komunitas anak punk yang ada dilapangan samber kota metro memiliki potret keluarga yang bermacam. Misalnya BS seorang perempuan yang ditinggal mati ibunya, bapaknya menikah lagi. Ia tinggal Bersama dengan bapak dan ibu tirinya. BS dalam kehidupan sehari-harinya dibatasi oleh bapaknya untuk berinteraksi dengan lingkungan. Ia menolak aturan bapaknya dan sering protes maka sering terjadi pertengkaran dikeluarga. Kemudian BS memutuskan untuk minggat dari rumah dan bergabung dengan komunitas punk. lingkungan sosial tempat ia tinggal juga menjadi faktor ia bergabung dengan komunitas punk. ia merasa tidak nyaman dengan lingkungan sosial dan budaya tempat ia tinggal. BS merasa terkekang dengan lingkungan sosial budaya tempat ia tinggal. Berbeda dengan BS, SA berasal dari keluarga Broken home, ibunya seorang itu rumah tangga yang sibuk dengan diri sendiri dan bapaknya seorang yang bekerja pulang mingguan dan saudara-saudaranya udah tidak tinggal bersama lagi. Ketika ayah dan ibunya berkumpul bersama sering terjadi pertengkaran, sehingga ia sendiri merasa tidak punya waktu untuk mengungkapkan perasaannya dan masalah-masalah pada dirinya. Karena tidak betah di rumah akhirnya ia mencoba untuk main kejalanan. Setelah sampai di jalanan ia menemukan kondisi yang berbeda. Ia merasakan di jalanan menemukan keluarga yang utuh yang sama-sama merasakan susah dan senang secara bersamaan.

Sementara itu potret keagamaan BS dan SA tidak terlalu peduli dengan nilai-nilai agama. Mereka merasa terkekang dengan nilainilai agama yang menurut mereka sering menggurangi kebebasan. Walaupun demikian mereka tetap melaksanakan ibadah shalat Walaupun tidak rutin. Kondisi BS dan SA berbeda dengan CE nilainilai agama dan ajaran agama Islam semisalnya shalat masih tetap 
dilaksanakannya sebagaimana mestinya walaupun sering di ujung waktu. CE ikut punk untuk menemukan kebebasan diri tanpa diikat oleh aturan-aturan yang mengekang kebebasan individu. Berdasarkan uraian di atas dapat kita ketahui bahwa seseorang ikut punk dipengaruhi oleh faktor pemahaman keagamaan, keluarga dan sosial budaya.

\section{KESIMPULAN}

Komunitas punk yang ada di lapangan samber kota Metro memiliki penampilan layaknya anak punk yang ada di berbagai daerah Komunitas punk yang ada di lapangan samber kota Metro ternyata tidak hanya warga Metro tetapi ada juga yang berasal dari kabupaten dan kota lain yang ada di Lampung. Komunitas punk yang ada di lapangan samber kota Metro banyak yang tidak paham dengan sejarah, jenis-jenis dan ideologi-ideologi punk, Motivasi mereka masuk punk lebih kepada mencara kebebasan dan ketenangan untuk mengatasi permasalahan-permasalahan yang mereka hadapi di keluarga dan sosial masyarat. Komunitas punk di lapangan samber kota Metro ini rata-rata berprofesi sebagai tukang parkir, pengamen, usaha sticker, sablon dan lainnya. Komunitas punk di lapangan samber kota Metro terdapat anak punk yang mengkonsumsi minuman keras

\section{DAFTAR PUSTAKA}

Abby Bank, Punk House (Interiors in Anarchy), USA: Abrams Image, 2007

Albert Bandura, Article of guide for Contructing Self Efficacy Scales. by Information Age Publishing, 2006

Albert Bandura, Self Efficacy, In V. S. Ramachaudran (Ed.), Encyclopedia of human behavior (Vol. 4, 77-81). New York: Academic Press, 1994

Alwisol, Psikologi Kepribadian. Malang : UMM Press, 2010 
Depdikbud, Kamus Besar Bahasa Indonesia, Jakarta: Balai Pustaka,1999.

Fathun Karib. "Sejarah Komunitas Punk." Artikel ini diakses pada 15 Agustus 2019, t.t. Http://jakartabeat.net/musik/kanalmusik/ulasan/147-sejarah-komunitaspunk-jakarta-bagian1.htm.

Jhon M. Echols, Hassan Shandly. Kamus Inggris Indonesia, Jakarta: Gramedia,1997, h. 456

John Martono, Arsita Pinandita, PUNK Fesyen-Subkultur-Identita, Yogyakarta: Halilintar Books,2009, h.29.

Judith Suissa. Anarchism and Education: a Philosophical Perspective, (New York: Routledge. 2006), h. 7

Peter Salim. The Contemporary English-Indonesia Dictionary, Jakarta:

Modern English Press, 1996, cet. 7, h. 1532

Poerwandari, Kristi. E., Pendekatan Kualitatif Dalam Penelitian Psikologi, Jakarta: LPSP3 Universitas Indonesia, 2008, h. 34

S. Wojowosito. Kamus Umum Lengkap, Bandung: Penerbit Pengarang, 1976, cet.7, h.312

Mujiadi, Psikologi Perkembangan, Yogyakarta: Gadjah Mada University Press, 2003

Murti. "Keberagamaan Komunitas Punk." Fakultas Ushuludin dan Filsafat Universitas Islam Negeri Jakarta, 2007.

Ridwan Hardiansyah. Sedikit Cerita Punk dari Bandar Lampung. Yogyakarta: Indie Book Corner, 2011

Santrock, J.W., Adolescence : Perkembangan Remaja Jakarta : Erlangga. 2005

Sheehan, Sean, Anarchism, London: Reaktion Books Ltd., 2004, h. 85.

Siti Sugiyati. "Fenomena Anak Punk Dalam Perspektif Teori Michel Foucault, Agama Dan Pendidikan." Fakultas Ilmu Tarbiyah Dan Keguruan Universita s Islam Negeri Syarif Hidayatullah Jakarta, 2014.

Sugiyono. Metode Penelitian Kuantitatif, Kualitatif dan RED,. Bandung: Alfabeta, 2009

S. Wojowosito. Kamus Umum Lengkap, Bandung: Penerbit Pengarang, 1976, cet.7, h.312 